\title{
Faktor-Faktor Karakteristik Kebijaksanaan Menurut Remaja
}

\author{
Riana Sahrani* \\ Fakultas Psikologi, Universitas Tarumanagara, Jakarta
}

\begin{abstract}
Abstrak
Penelitian terdahulu menunjukkan bahwa budaya mempengaruhi bagaimana individu mendefinisikan kebijaksanaan. Penelitian sebelumnya juga sudah berupaya memahami kebijaksanaan berdasarkan konteks Barat dan beberapa di negara Timur, tapi belum ada yang mencoba memahaminya di konteks Indonesia. Penelitian ini berupaya mengisi kekosongan tersebut. Secara spesifik, kami berupaya untuk mengembangkan skala kebijaksanaan pada remaja. Kami melakukan penelitian ini dalam dua tahap. Pada tahap pertama, partisipan kami adalah 349 remaja berusia 15 hingga 21 tahun. Kami menanyakan partisipan untuk mengindikasikan karakteristik kebijaksanaan menurut mereka. Dari tahapan ini, kami memperoleh 52 karakteristik kebijaksanaan. Pada tahapan kedua, kami mengembangkan kuesioner berdasarkan respon jawaban yang muncul pada tahapan pertama. Total terdapat 52 item dalam kuesioner ini. Kami menganalisis data pada tahapan kedua ini dengan menggunakan Exploratory Factor Analisis (EFA). Berdasarkan hasil analisis diperoleh 44 butir karakteristik kebijaksanaan. Butir-butir tersebut kemudian dikelompokkan menjadi 3 faktor, yaitu faktor: (1) berpikir Cerdas; (2) kepribadian positif; (3) keterandalan dalam bertindak. Butir yang paling berkontribusi dari faktor berpikir cerdas adalah "hati-hati dalam bertindak" $(0,790)$; selanjutnya butir yang paling berkontribusi dari faktor kepribadian positif adalah "setia" $(0,701)$; terakhir butir yang paling berkontribusi dari faktor keterandalan dalam bertindak adalah "mampu mengemukakan pendapat dan berkomunikasi" $(0,731)$.
\end{abstract}

Kata kunci: Kebijaksanaan, karakteristik kebijaksanaan, remaja

\begin{abstract}
Previous studies indicate that culture influences how people define wisdom. While there have been studies that attempt to examine wisdom in Western contexts and few studies in Eastern contexts, there has not been studies that attempt to examine in Indonesia context. Present study aims to fill the gap. We develop an Indonesia version of wisdom scale, in particular for adolescence. We conducted this study in two stages. At the first stage, our participants were 349 adolescence, ages ranged from 15 to 21 years also. We asked participants to indicate their opinion about the characteristics of wisdom. From this stage, we obtained 52 characteristics of wisdom. At the second stage, we developed a questionnaire based on responses we obtained from the first stage. In total we had 52 items in this questionnaire. We then employed 153 adolescence as participants to fill the questionnaire. We analyzed the data from the second stage with Exploratory Factor Analysis (EFA). The analysis showed that 44 items had good factor loadings and these items could be grouped into three factors: (1) smart thinking; (2) positive personality; (3) reliability in acting. The most contributing point of the smart thinking factor is "be careful in acting" (.790); then the most contributing item of positive personality factors is "loyal" $(0,701)$; the last point that most contributes to the reliability factor in acting is "able to express opinions and communicate" $(0,731)$.
\end{abstract}

Keywords: Wisdom, characteristics of wisdom, adolescence

\section{Pendahuluan}

Penelitian ini merupakan studi eksplorasi karakteristik kebijaksanaan remaja. Penelitian ini dilaksanakan karena latar belakang teoretis, yaitu belum adanya alat ukur baku yang mengukur kebijaksanaan (wisdom), khusus untuk orang Indonesia. Fenomena yang ada saat ini mengindikasikan bahwa kebijaksanaan kurang diperlihatkan oleh para remaja, misalnya maraknya peristiwa bullying atau kekerasan di sekolah. Padahal remaja itu sendiri sebetulnya berpotensi untuk menjadi orang yang bijaksana, seperti halnya orang dewasa (Pasupathi, Staudinger, \& Baltes, 2001).

Alat ukur yang selama ini dipakai kebanyakan mengacu pada kuesioner 3D-WS (Three-Dimentional Wisdom Scale) yang disusun oleh Ardelt (2003). Garcia-Campayo dkk. (2018) memakai alat ukur ini untuk mengukur kebijaksanaan pada orang Spanyol, 
sementara Sahrani, Matindas, Takwin, dan Mansoer (2014) memakai alat ukur ini guna melihat kebijaksanaan orang yang direkomendasikan sebagai orang yang bijaksana di Jakarta (Indonesia). Namun demikian, Ardelt sendiri adalah seorang Sosiolog yang meneliti kebijaksanaan berdasarkan sampel dunia 'Barat'/Amerika, sehingga belum bisa dikatakan mewakili kebijaksanaan yang digali dari ilmu Psikologi ataupun kebijaksanaan 'ala' dunia Timur, khususnya Indonesia. Maka dari itu peneliti bermaksud membuat suatu alat ukur yang benarbenar menggambarkan kebijaksanaan orang Indonesia, yang berbasis Pancasila sebagai dasar negara Indonesia. Hal ini karena dalam butir-butir Pancasila terkandung nilai-nilai yang menggambarkan kebijaksanaan (Sahrani, Suyasa, \& Basaria, 2018).

Peneliti lain yang juga membuat alat ukur kebijaksanaan sesuai dengan negara masing-masing antara lain Smith dan Baltes (1990) dari Jerman yang membuat alat ukur Wisdom-Related Knowledge, serta Webster (2003) dari Kanada yang membuat alat ukur Self-Assessed Wisdom Scale (SAWS), atau bahkan dari Amerika sendiri, yaitu oleh Thomas dkk. (2017) yang membuat alat ukur The San Diego Wisdom Scale (SDWISE) dengan menghubungkan kebijaksanaan dengan neurobiologi.

Pada dasarnya kebijaksanaan tidak mengenal usia, karena siapapun bisa menjadi orang yang bijak, tidak terkecuali anak-anak. Gluck, Bischof, dan Siebenhuner (2012) juga sudah meneliti apa sajakah karakteristik kebijaksanaan menurut anak Sekolah Dasar (SD) di Austria. Namun demikian, beberapa temuan menegaskan bahwa pada saat remajalah bibit-bibit kebijaksanaan itu muncul (Ardelt, 2008; Benedikovicova \& Ardelt, 2008; Pasupathi dkk. 2001). Remaja yang sudah mencapai kemampuan berpikir secara hypothetical deductive reasoning akan lebih mampu menganalisis masalah dan mencari solusi penyelesaian masalahnya. Dalam hal ini para remaja disimpulkan mempunyai bibit kebijaksanaan, karena mempunyai pengetahuan yang cukup tentang dunia sehingga punya bekal untuk memecahkan permasalahan sehari-hari.

Selain itu, peneliti bertujuan meneliti karakteristik kebijaksanaan versi orang Indonesia karena terdapat teori yang menjelaskan bahwa kebijaksanaan antara orang Barat dan Timur ada perbedaannya, dikarenakan ada pengaruh budaya (Takahashi \& Bordia, 2000; Walsh, 2015). Kebijaksanaan versi Barat lebih menekankan pada bagaimana orang mengatasi permasalahan, jadi lebih ke arah kognitif. Sementara dalam budaya Timur, kebijaksanaan lebih dikaitkan dengan domain afektif, yaitu bagaimana orang dapat menyesuaikan diri secara harmonis dengan orang lain dan lingkungannya. Pentingnya faktor budaya juga mendorong beberapa peneliti dari berbagai negara untuk membuat alat ukur kebijaksanaannya sendiri, misalnya Webster (2003) membuat alat ukur "Self-assessed Wisdom Scale" untuk mengukur partisipan di Kanada, Grenee dan Brown (2009) menyusun "The Wisdom
Development Scale" untuk mengukur orang Amerika, dan lainnya.

Kajian kebijaksanaan versi Timur salah satunya dari Indonesia, yaitu temuan Basri (2001) mengenai karakteristik kebijaksanaan menunjukkan bahwa orang yang bijaksana itu mempunyai kondisi spiritual moral yang tinggi. Namun peneliti juga sudah melakukan penelitian sejenis dan mendapatkan hasil bahwa kepercayaan diri memegang kunci utama kebijaksanaan (Sahrani dkk., 2014). Dengan demikian dalam rangkaian penelitian kebijaksanaan ini, peneliti melakukan penelitian ulang untuk lebih mendapatkan hasil yang komprehensif, selain juga menyempurnakan penelitian sejenis karena belum memasukkan unsur nilai-nilai Pancasila dalam alat ukur kebijaksanaan tersebut.

Kebijaksanaan diartikan sebagai suatu keahlian yang luar biasa dalam menghadapi permasalahan mendasar mengenai arti kehidupan, serta bagaimana menjalani kehidupan dengan baik (Baltes \& Smith, 1990; Baltes \& Staudinger, 1993, 2000). Baltes dan Smith (1990) memberikan penjelasan lebih lanjut, keahlian yang luar biasa tersebut dimaksudkan bahwa orang yang ahli dapat dibedakan dari orang yang belum ahli dalam memecahkan masalah kehidupan yang kompleks. Maka dari itu orang yang bijaksana diprediksi mampu mengatasi permasalahan yang ada dalam kehidupannya sehari-hari, yang berkaitan dengan norma dan interaksi dengan orang lain di lingkungan sosial, sehingga tercipta kondisi yang harmonis antara individu dengan lingkungannya. Dalam penelitian ini kebijaksanaan diartikan sebagai kepandaian individu dalam menggunakan akalbudinya berdasarkan pengalaman dan pengetahuan, bersamaan dengan pengintegrasian pikiran, perasaan, dan tingkah laku, serta adanya kemauan untuk mengevaluasi diri, dalam menilai dan memutuskan suatu masalah, sehingga tercipta keharmonisan antara individu dan lingkungan.

Ardelt (2003) menyatakan bahwa kebijaksanaan adalah integrasi aspek kognitif, reflektif, dan afektif. Dimensi kognitif mengacu pada kemampuan individu dalam memahami kehidupan, yang berhubungan dengan faktor intrapersonal dan interpersonal (Ardelt, 2000, 2003; Sternberg, 1990). Dimensi afektif adalah adanya emosi dan tingkah laku positif, misalnya adanya perasaan dan tindakan berdasarkan simpati dan kasih sayang terhadap orang lain (Ardelt, 2003). Dimensi reflektif mengacu pada kemampuan individu dalam memandang suatu fenomena atau masalah dari berbagai sudut pandang, sehingga menimbulkan self-awareness dan self-insight (Ardelt, 2003; Kramer, 1990).

Hal yang harus dikuasai oleh orang yang bijaksana, yaitu keahlian dalam life planning (perencanaan kehidupan), life management (pengelolaan kehidupan), dan life review (pengkajian kehidupan). Semua hal di atas membutuhkan adanya pengetahuan yang luas mengenai fakta-fakta dalam kehidupan), pengetahuan yang luas mengenai strategi dalam menjalani kehidupan, pengetahuan mengenai konteks dan nilai dalam kehidupan, dan 
pengetahuan mengenai ketidakpastian dalam kehidupan (Baltes \& Smith, 1990).

Selanjutnya, Basri (2006) menemukan lima karakteristik orang yang bijaksana, menurut pandangan orang Indonesia. Kelima karakteristik itu adalah: (a) kondisi spiritual-moral (bertakwa, religius/beriman, saleh, tawakal, sederhana/bersahaja kehidupannya, tutur kata halus/lemah lembut/sopan santun, tabah, dan tegas), (b) kemampuan hubungan antar manusia (murah hati, mau berkorban, penyayang pada semua, tulus ikhlas, mengayomi/melindungi, pemaaf, penuh pengertian), (c) kemampuan menilai dan mengambil keputusan (meninjau permasalahan dari berbagai sudut pandang, lebih memperhatikan kepentingan orang banyak daripada kepentingan pribadi, mampu memutuskan secara tepat, filosofis/berpandangan menyeluruh terhadap kehidupan, adil), (d) kondisi personal (mawas diri, bertanggungjawab, konsekuen, percaya diri), dan (e) kemampuan khusus/istimewa (cerdas/kompeten, intuitif, berpengetahuan dan berwawasan luas, berempati).

Sahrani dkk. (2014) memakai alat ukur karakteristik orang yang bijaksana berdasarkan temuan dari Basri (2001). Namun dari penelitian tersebut didapatkan hasil bahwa kebijaksanaan mempunyai karakteristik utama yaitu kepercayaan diri. Jadi bukan seperti temuan Basri, bahwa orang yang bijaksana dilihat sebagai orang yang bertakwa dan menjalankan agamanya. Temuan Sahrani dkk., justru lebih mendekati temuan Ardelt (2003), karena kepercayaan diri lebih mendekati aspek kognitif. Maka dapat dikatakan bahwa sejauh pengetahuan peneliti, sampai saat ini belum ada peneliti yang membuat alat ukur Kebijaksanaan versi Indonesia, yang sesuai dengan nilai dan budaya Indonesia. Penelitian ini bertujuan untuk mendapatkan alat ukur Kebijaksanaan, berdasarkan penelitian mengenai apa sajakah karakteristik orang yang bijaksana versi orang Indonesia, yang sesuai dengan nilai dan budaya orang Indonesia.

Penelitian ini ingin mendapatkan hasil berupa karakteristik orang yang bijaksana menurut orang Indonesia, dimulai dari remaja. Apabila telah ditemukan karakteristiknya, maka dapat dilanjutkan dengan pembuatan alat ukur kebijaksanaan. Alat ukur kebijaksanaan ini selanjutnya dapat digunakan untuk penelitian dengan variabel-variabel psikologis lainnya, untuk mencari solusi dari permasalahan yang terjadi di Indonesia saat ini khususnya. Selanjutnya, dapat dirancang suatu intervensi untuk meningkatkan kesejahteraan psikologis, khususnya dalam bidang Pendidikan. Rumusan masalah dalam penelitian ini yaitu: Apakah karakteristik kebijaksanaan menurut remaja?

\section{Metode Penelitian}

Desain penelitian ini adalah kuantitatif non eksperimental, dengan menggunakan alat ukur berupa kuesioner. Subyek yang sesuai dengan karakteristik sampel penelitian berjumlah 502 orang remaja (Tahap 1 dan 2), yang berusia 12 - 21 tahun, berpendidikan SMP, SMA, dan Perguruan Tinggi di Jakarta, Bogor, Depok, Tangerang, dan Bekasi (Jabodetabek). Agama, tingkat pendidikan, jenis kelamin, pekerjaan, dan domisili tidak dibatasi. Teknik pengambilan sampel adalah accidental sampling. Penelitian ini terdiri dari 2 tahap, yaitu: tahap I mengumpulkan karakteristik kebijaksanaan berdasarkan pandangan remaja dan tahap II membuat kuesioner untuk menguji karakteristik kebijaksanaan yang telah didapat di tahap I. Instrumen penelitian yang digunakan adalah dua macam kuesioner, yaitu kuesioner tahap I berupa pertanyaan terbuka mengenai apa saja karakteristik orang yang bijaksana menurut remaja. Kuesioner tahap II dibuat berdasarkan hasil jawaban kuesioner tahap I, untuk diujikan dan kemudian akan digabungkan dengan hasil penelitian selanjutnya pada orang dewasa dan juga lanjut usia.

Peneliti kemudian melakukan elisitasi atau perolehan jawaban atas pertanyaan mengenai ciriciri atau karakteristik orang yang bijaksana. Hal ini dilakukan dengan cara mengumpulkan pendapatatau jawaban terbuka sebanyak-banyaknya dari responden penelitian. Kemudian, jawaban-jawaban tersebut dikelompokkan berdasarkan persamaan arti. Kemudian, dipilih sejumlah karakteristik yang disebutkan paling sering disebutkan oleh para responden penelitian ini. Selanjutnya karakteristik kebijaksanaan yang sudah dipilih dijadikan butirbutir untuk skala penilaian yang memiliki kontinum mulai dari 1 (sangat tidak menggambarkan karakteristik kebijaksanaan) hingga 7 (sangat menggambarkan karakteristik kebijaksanaan). Berikutnya, kuesioner tersebut dibagikan pada responden yang berbeda. Pengolahan data dalam penelitian ini menggunakan metode Exploratory Factor Analysis (EFA), karena metode ini cocok untuk mendapatkan pengelompokan faktor-faktor kebijaksanaan menurut para remaja, sesuai dengan tujuan penelitian di awal.

\section{Hasil Penelitian}

\section{Elisitasi Pertanyaan Terbuka}

Responden yang diperoleh pada penelitian tahap 1 berjumlah 349 orang. Adapun perincian respondennya sebagai berikut: responden remaja wanita sebanyak 220 orang dan remaja pria sebanyak 129 orang, yang semuanya berusia antara 14 sampai 21 tahun. Responden sedang menempuh Pendidikan di SMP (82 orang), SMA (161 orang), atau Perguruan Tinggi (106 orang). Jawaban yang telah dituliskan responden, kemudian kami input. Contohnya dapat dilihat pada tabel 1 .

Jawaban dari 349 responden, kemudian dikelompokkan dalam satu topik, sehingga menjadi satu karakteristik setiap kolom jawabannya. Proses ini menghasilkan 504 karakteristik orang yang 
Tabel 1. Contoh Elisitasi Karakterisktik Kebijaksanaan Menurut Remaja

\begin{tabular}{|c|c|c|c|}
\hline No. & Usia & Pendidikan & Jawaban \\
\hline 1 & 14 & SMP & $\begin{array}{l}\text { orang yang tegas, percaya diri, mempunyai wawasan ilmu yang luas, dan } \\
\text { mau menasehati orang yang salah. }\end{array}$ \\
\hline 2 & 15 & SMA & orang yang mengambil keputusan tanpa merugikan pihak lain. \\
\hline 3 & 15 & SMA & $\begin{array}{l}\text { dapat membedakan mana yang benar dan salah, menghargai orang lain, } \\
\text { bersikap tenang dalam keadaan sulit, teliti, jujur, percaya diri, tidak } \\
\text { egois. }\end{array}$ \\
\hline 4 & 17 & SMA & pemaaf, dapat mengambil keputusan. \\
\hline 5 & 17 & SMA & $\begin{array}{l}\text { melihat orang secara keseluruhan bukan dari kesalahan yang dibuat, } \\
\text { bersikap adil terhadap siapapun, tidak mengambil keputusan yang } \\
\text { menurut dia benar. }\end{array}$ \\
\hline 6 & 18 & SMA & $\begin{array}{l}\text { orang yang bisa tegas dalam mengambil keputusan dan tau mana yang } \\
\text { benar atau salah, mementingkan keperluan bersama bukan kepent- } \\
\text { ingan pribadi atau egois. }\end{array}$ \\
\hline 7 & 19 & PT & dewasa, bisa berpikir jernih, tindakannya sesuai dengan omongannya. \\
\hline
\end{tabular}

Tabel 2. Contoh Karakteristik Kebijaksanaan Menurut Remaja Sebelum Dikelompokkan

\begin{tabular}{ll}
\hline No. & Karakteristik sebelum dikelompokkan \\
\hline 1 & Berperilaku positif \\
2 & Mudah bersosialisasi \\
3 & Tegas \\
4 & Adil \\
5 & Amanah \\
6 & Berbicara sesuai fakta \\
7 & Beriman \\
8 & Berilmu \\
9 & Berkharisma \\
10 & Berani mengambil keputusan \\
11 & Beretika \\
12 & Beragama \\
13 & Berpikir diluar ordinary thinking \\
\hline
\end{tabular}

bijaksana menurut remaja. Pada tahapan ini ada beberapa karakteristik yang sama, yang tetap dituliskan satu persatu, yang kemudian akan dikelompokkan tahapan selanjutnya. Adapun contoh karakteristik tersebut dapat dilihat pada tabel 2.

Peneliti kemudian mengklasifikasi jawabanjawaban yang serupa dan memiliki pengertian yang sama ke dalam satu kelompok jawaban. Maka dari 504 kriteria, setelah dikelompokkan menjadi 85 kriteria. Adapun contohnya dapat dilihat pada tabel 3.

Peneliti selanjutnya menelaah kembali dan menggabungkan karakteristik yang mempunyai makna dan sifat yang serupa dengan bantuan seorang rater. Proses ini menghasilkan 52 karakteristik final dari 85 karakteristik. Dengan demikian 52 butir karakteristik orang yang bijaksana inilah yang selanjutnya akan dibuat dalam bentuk kuesioner dan diberikan kembali pada responden yang berbeda. Hasilnya kemudian akan diolah dengan program statistik, yaitu analisa faktor, untuk mendapatkan karakteristik yang baku beserta aspek-aspek (pengelompokan bakunya). Adapun 52 karakteristik itu dapat dilihat pada tabel 4 .

\begin{tabular}{ll}
\hline No. & Karakteristik sebelum dikelompokkan \\
\hline 14 & Berpikir positif \\
15 & Berkomitmen tinggi \\
16 & Berpikir kritis \\
17 & Berpendirian \\
18 & Berpikir dewasa \\
19 & Berkata benar \\
20 & Berpikir logis dan rasional \\
21 & Berpikir objektif \\
22 & Berpikir sebelum bertindak \\
23 & Berpikir maju \\
24 & Berpikir positif \\
25 & Berpendirian \\
& \\
\hline
\end{tabular}

\section{Hasil Uji Exploratory Factor Analysis (EFA)}

Pada penelitian tahap 2, data yang dapat diolah sebanyak 153. Responden penelitian ini berusia 1521 tahun, dengan rata-rata usia partisipan adalah 18 tahun $(\mathrm{M}=18.71, \mathrm{SD}=1.516)$. Jenis kelamin terbanyak adalah perempuan, sebanyak $71,2 \%$, sedangkan laki-laki sebanyak 28,8\%. Pendidikan terakhir responden yang terbanyak adalah SMA sebesar 88,2\%, dilanjutkan oleh Pendidikan S1 sebanyak 7,2\%, dan SMP 4,6\%. Pekerjaan responden paling banyak adalah kuliah sebesar $84,3 \%$, diikuti oleh pekerjaan sebagai pelajar/sekolah sebesar $11,1 \%$.

Pengolahan data dalam penelitian ini menggunakan metode Exploratory Factor Analisis (EFA). Berdasarkan hasil analisis faktor terhadap 52 butir pernyataan yang menggambarkan karakteristik kebijaksanaan, ditemukan terdapat 10 faktor dengan nilai eigenvalues $>1,00$. Namun apabila mengacu pada grafik scree plot (dapat dilihat pada gambar di bawah ini), pembagian faktor secara signifikan terdapat pada 3 faktor. 
Tabel 3. Contoh Karakteristik Kebijaksanaan Menurut Remaja Setelah Dikelompokkan

\begin{tabular}{lll}
\hline No. & Karakteristik sebelum pengelompokkan & Karakteristik sesudah pengelompokkan \\
\hline 1 & Adil & Adil \\
2 & Dapat membagi tugas secara seimbang & Adil \\
3 & Dapat mengakomodasi kebutuhan orang banyak & Adil \\
4 & Dapat menjadi pemimpin dimanapun ia berada & Berjiwa kepemimpinan \\
5 & Memimpin dengan baik diri sendiri dan orang lain & Berjiwa kepemimpinan \\
6 & Berpikir jernih & Berpikir positif \\
7 & Berpikir positif & Berpikir positif \\
8 & Berpikir positif & Berpikir positif \\
9 & Memikirkan masa depan & Berpikiran maju \\
10 & Pemikiran jangka panjang & Berpikiran maju \\
11 & Selalu berpikir jauh kedepan & Berpikiran maju \\
12 & Berilmu & Berwawasan luas \\
13 & Berwawasan luas & Berwawasan luas \\
14 & Punya pengetahuan luas & Berwawasan luas \\
15 & Wawasan luas & Berwawasan luas \\
16 & Up to date & Berwawasan luas \\
17 & Wawasan luas & Berwawasan luas \\
18 & Kritis & Cerdas, cerdik \\
19 & Pandai & Cerdas, cerdik \\
20 & Pemikir & Cerdas, cerdik \\
21 & Tajam pikiran & Cerdas, cerdik \\
22 & Pintar & Cerdas, cerdik \\
23 & Dapat mengatur waktu & disiplin \\
24 & Disiplin & disiplin \\
25 & Mampu dalam time management & disiplin \\
\hline
\end{tabular}

Tabel 4. Karakteristik Kebijaksanaan Menurut Remaja

\begin{tabular}{|c|c|c|c|}
\hline No. & $\begin{array}{c}\text { Karakteristik Orang yang Bijaksana } \\
\text { menurut Remaja }\end{array}$ & No. & $\begin{array}{l}\text { Karakteristik Orang yang Bijaksana menurut } \\
\text { Remaja }\end{array}$ \\
\hline 1 & Adil & 26 & $\begin{array}{l}\text { Mampu menghadapi dan mencari solusi masa- } \\
\text { lah }\end{array}$ \\
\hline 2 & Amanah & 27 & Mampu menilai diri sendiri dan orang lain \\
\hline 3 & Apa adanya & 28 & Mandiri \\
\hline 4 & Berani mengambil keputusan & 29 & Mau bekerja keras, tidak mudah menyerah \\
\hline 5 & Berjiwa besar, mau memaafkan orang lain & 30 & Mau menerima kritik dan pendapat orang lain \\
\hline 6 & $\begin{array}{l}\text { Berjiwa kepemimpinan, berkharisma, ber- } \\
\text { wibawa, menjadi teladan }\end{array}$ & 31 & Mau menolong, tulus ikhlas \\
\hline 7 & Berkomitmen & 32 & $\begin{array}{l}\text { Memikirkan dampak keputusan, mempertim- } \\
\text { bangkan setiap tindakan }\end{array}$ \\
\hline 8 & $\begin{array}{l}\text { Berpikir positif, berpikiran maju, berwawa- } \\
\text { san luas }\end{array}$ & 33 & Memiliki tujuan dan dan makna kehidupan \\
\hline 9 & Bersyukur & 34 & Memperhatikan kerapihan \\
\hline 10 & Bertanggungjawab & 35 & Mempunyai banyak pengalaman hidup \\
\hline 11 & Bertindak tepat & 36 & Mempunyai hati nurani \\
\hline 12 & Cerdas, cerdik, kritis, kreatif & 37 & Mempunyai prinsip dan nilai moral yang baik \\
\hline 13 & Cinta damai & 38 & Mempunyai sikap nasionalisme \\
\hline 14 & Dermawan & 39 & Menaati aturan yang berlaku di masyarakat \\
\hline 15 & Disiplin & 40 & Menepati janji, dapat dipercaya, jujur \\
\hline 16 & Empati & 41 & $\begin{array}{l}\text { Menerima kelemahan diri dan mengakui } \\
\text { kesalahan }\end{array}$ \\
\hline 17 & Fleksibel, mau menerima perubahan & 42 & Menghormati orang tua, orang yang lebih tua \\
\hline 18 & Hati-hati dalam berbicara dan berindak & 43 & Menjalankan agamanya \\
\hline 19 & Hemat & 44 & Peduli orang lain dan lingkungan \\
\hline 20 & Humoris & 45 & Percaya diri \\
\hline 21 & Konsisten, berkomitmen & 46 & Ramah, murah senyum, sopan, beretika \\
\hline 22 & $\begin{array}{l}\text { Mampu bekerjasama dan menyesuaikan } \\
\text { diri dengan orang lain }\end{array}$ & 47 & Rendah hati \\
\hline 23 & $\begin{array}{l}\text { Mampu memotivasi dan menasehati orang } \\
\text { lain }\end{array}$ & 48 & Sabar, tenang \\
\hline 24 & $\begin{array}{l}\text { Mampu mengemukakan pendapat, berko- } \\
\text { munikasi }\end{array}$ & 49 & Setia \\
\hline \multirow[t]{3}{*}{25} & Mampu mengendalikan emosi & 50 & Tegas \\
\hline & & 51 & Teliti \\
\hline & & 52 & Tidak mementingkan diri sendiri \\
\hline
\end{tabular}




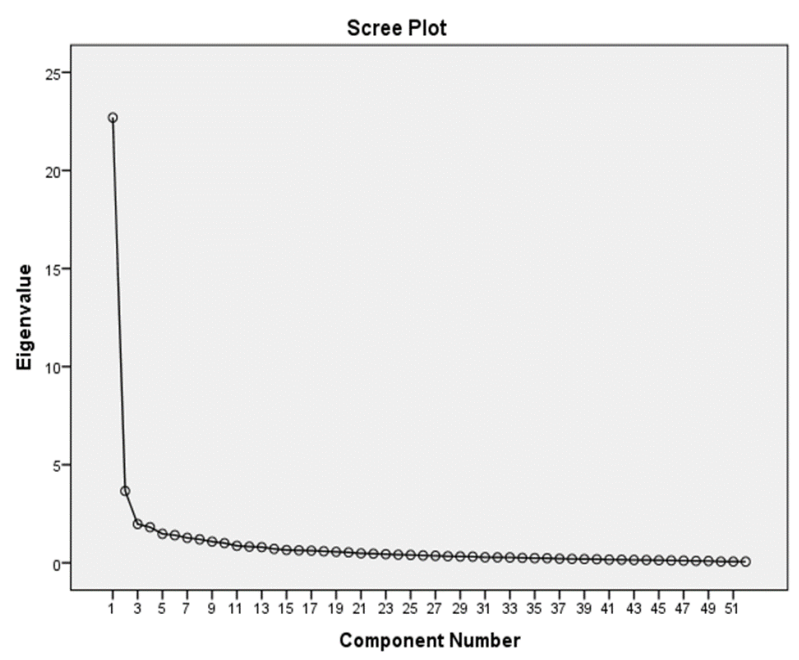

Gambar 1. Grafik Scree Plot

Setelah melakukan uji dengan rotasi varimax, butir-butir yang memiliki nilai factor loading $>0,5$ dikelompokkan ke dalam satu kelompok faktor. Dari 52 butir pernyataan, terdapat 7 butir yang dibuang karena memiliki nilai factor loading < 0,5 (butir 17, $19,23,33,42,48,52)$. Selain itu, terdapat 1 butir yang dibuang karena memiliki nilai factor loading $>0,5$ pada dua faktor yang berbeda (butir 6).

Gambaran nilai factor loading butir karakteristik kebijaksanaan dapat dilihat pada lampiran tabel A.1. Setelah 8 butir tadi dibuang, maka hasilnya ada 44 butir yang terbagi menjadi 3 dimensi karakteristik kebijaksanaan menurut remaja (lihat pada tabel A.2. di lampiran).

Berdasarkan hasil pengelompokan butir tersebut, peneliti menamakan faktor 1 sebagai "Berpikir Cerdas" (terdiri dari 15 karakteristik); faktor 2 sebagai "Kepribadian Positif" (terdiri dari 17 karakteristik); dan faktor 3 sebagai "Keterandalan dalam Bertindak" (terdiri dari 12 butir). Butir yang paling berkontribusi dari Faktor Berpikir Cerdas adalah "hati-hati dalam bertindak" $(0,790)$; selanjutnya butir yang paling berkontribusi dari Faktor Kepribadian Positif adalah "setia" $(0,701)$; terakhir butir yang paling berkontribusi dari Faktor Keterandalan dalam Bertindak adalah "mampu mengemukakan pendapat dan berkomunikasi" $(0,731)$. Kelebihan penelitian ini adalah penelitian karakteristik kebijaksanaan menurut remaja, yang belum banyak dilakukan sebelumnya di Indonesia.

\section{Diskusi}

Hasil dari perhitungan analisa faktor menunjukkan bahwa ada pengelompokan butir karakteristik kebijaksanaan menurut remaja, menjadi tiga faktor, yaitu: berpikir cerdas, kepribadian positif, dan keterandalan dalam bertindak. Apabila dilihat dari jumlah pengelompokan, maka hasil penelitian ini sejalan dengan temuan dari penelitian yang dilakukan di negara Barat yaitu oleh Clayton dan
Birren (dalam Baltes \& Staudinger, 1996), yang mendapatkan bahwa karakteristik kebijaksanaan itu terdiri dari tiga faktor, yaitu kognitif, afektif, dan reflektif. Kemudian ditemukan hal yang sama oleh Ardelt (2003).

Namun demikian, bila ditinjau dari segi jumlah juga, maka hasil penelitian ini agak berbeda dari temuan penelitian "Timur", yaitu temuan penelitian Basri (2006) yang menggambarkan subyek Indonesia. Basri menghasilkan temuan 5 faktor yang menggambarkan karakteristik kebijaksanaan, yaitu: Kondisi spiritual moral tinggi, Mempunyai hubungan antar manusia yang baik, Mempunyai kemampuan menilai dan mengambil keputusan, Kondisi personal yang optimal, dan Mempunyai kemampuan khusus/istimewa. Ada 6 butir karakteristik kebijaksanaan yang ada dalam Basri namun tidak ada dalam penelitian ini (Sahrani dkk., 2014), yaitu: religius/beriman, saleh, tawakal, mengayomi/ melindungi, filosofis/berpandangan menyeluruh terhadap kehidupan, dan intuitif. Demikian pula sebaliknya, ada 6 butir yang ada dalam Sahrani, namun tidak ada dalam Basri, yaitu: amanah, humoris, mempunyai hati nurani, mempunyai sikap nasionalisme, bersyukur, dan memperhatikan kerapian. Kondisi ini mungkin saja terjadi karena perbedaan kurun waktu pengukuran, yaitu adanya perbedaan waktu selama 18 tahun (penelitian Basri dilakukan pertama kali tahun 2001), sehingga kemungkinan terjadi pergeseran nilai dan budaya pada orang Indonesia secara umum (yang tentunya diperlukan penelitian dan pembahasan lebih lanjut).

Argumentasi lainnya adalah, penelitian Basri dilakukan pada orang dewasa muda, dewasa madya, dan lanjut usia (tiga tahapan usia), sedangkan pada penelitian ini baru hanya dilakukan pada usia remaja (satu tahapan usia). Jadi ada perbedaan cohort, sehingga kemungkinan besar juga ada perbedaan sudut pandang. Namun, yang unik dari penelitian ini adalah para remaja yang menjadi responden penelitian ini sudah memikirkan konsep yang berhubungan dengan Pancasila (yang belum ada pada penelitian Basri atau sebelumnya), yaitu: "mempunyai sikap nasionalisme".

Kajian lebih lanjut mengenai temuan ini adalah remaja merupakan individu, yang pada umumnya mempunyai pengalaman hidup yang tidak sebanyak orang dewasa atau lanjut usia. Namun Pasupathi dkk. (2001) sudah dapat memastikan bahwa remaja sebenarnya dapat berpotensi untuk menjadi orang yang bijaksana, karena remaja sudah mempunyai 'bibit-bibit' kebijaksanaan. Akan tetapi temuan penelitian yang lebih baru menegaskan bahwa pengalaman hiduplah, terutama pengalaman hidup sulit, yang lebih berperan dalam membentuk orang menjadi bijaksana (Sahrani dkk., 2014; Westrate \& Gluck, 2017; Yang, 2017).

Jadi remaja yang mempunyai pengalaman hidup sulit lebih berpotensi menjadi orang yang bijaksana. Selain itu, refleksi pengalaman hidup yang sulit juga sangat berperan terhadap perolehan kebijaksanaan (Sahrani dkk., 2014). Hal serupa 
dinyatakan oleh Grossman (2018) berdasarkan hasil penelitiannya bahwa individu yang merefleksikan diri akan mendukung diperolehnya kebijaksanaan dalam diri individu tersebut. Grossman juga menawarkan suatu ide bahwa berpikir bijaksana itu dapat diajarkan melalui kombinasi pengajaran, misalnya tentang sejarah kebijaksanaan khususnya, contoh-contoh pengalaman hidup orang yang bijak, dan melalui refleksi pengalaman hidup tokoh-tokoh yang bijaksana. Bahkan, Ardelt (2018) meneliti tentang bagaimana mengajarkan kebijaksanaan pada mahasiswa. Ia memberikan intervensi tentang pengantar filsafat, yang dikhususkan pada sejarah dan juga tentang tokoh kebijaksanaan.

Penelitian ini menggambarkan bahwa terdapat perbedaan 6 butir yang dari penelitian Basri (2006), yaitu amanah, humoris, mempunyai hati nurani, mempunyai sikap nasionalisme, bersyukur, dan memperhatikan kerapian, menandakan bahwa remaja juga dapat membedakan mana orang yang bijaksana dan mana yang tidak. Remaja membutuhkan panutan atau contoh konkret bagaimana agar dapat bersikap dan berperilaku bijaksana (seperti disebutkan dalam butir tersebut, misalnya antara lain bagaimana berperilaku amanah (memegang janji dan tanggung jawab), bersyukur, dan mempunyai sikap nasionalisme. Tokoh panutan terdekat bagi remaja tentu saja orang tua dan guru. Maka orang tua dan guru dapat memberikan contoh, sekaligus mengajarkan apakah itu kebijaksanaan dan manfaat apa yang akan diperoleh kalau individu menjadi orang yang bijaksana. Apalagi bila orang tua dan guru dapat menyampaikannya dengan cara yang humoris, seperti yang disebutkan remaja sebagai salah satu karakteristik dari orang yang bijaksana.

Lebih lanjut, apabila kita membahas mengenai butir "mempunyai sikap nasionalisme", maka peneliti dan rekan-rekan (Sahrani, Suyasa, \& Basaria, 2018) juga membuat alat ukur mengenai kebijaksanaan, yang diberi nama "Kebijaksanaan Berbasis Pancasila". Alat ukur ini mengacu pada butir-butir Pancasila, yang diharapkan dapat mengakomodasi butir "mempunyai sikap nasionalisme" dari hasil penelitian ini. Alat ukur ini nantinya akan dipakai untuk meneliti kebijaksanaan orang Indonesia, dikaitkan dengan variabel-variabel lain. Hasil-hasil penelitian tersebut nantinya diharapkan dapat dibuat menjadi suatu intervensi yang dapat berguna dan diaplikasikan bagi kesejahteraan rakyat Indonesia.

Meski penelitian ini telah memberikan sumbangan teoretis yang berharga, perlu diakui bahwa penelitian ini memiliki keterbatasan, yaitu jumlah sampel yang tidak terlalu banyak, khususnya pada tahapan kedua penelitian. Oleh karena itu, penelitian selanjutnya perlu menggunakan responden yang lebih banyak untuk mendapatkan temuan yang lebih kuat. Selain itu juga, masih terkait metodologi, rater yang dilibatkan dalam penelitian ini hanya satu orang, sehingga pengelompokan respon yang muncul hanya berdasarkan pemahaman Bahasa dan konsep satu penilai saja.

\section{Kesimpulan}

Hasil penelitian ini adalah terdapat tiga faktor yang mempengaruhi kebijaksanaan menurut remaja, yaitu faktor: (1) berpikir cerdas; (2) kepribadian positif; (3) keterandalan dalam bertindak. Butir yang paling berkontribusi dari faktor berpikir cerdas adalah "hati-hati dalam bertindak" $(0,790)$; selanjutnya butir yang paling berkontribusi dari faktor kepribadian positif adalah "setia" $(0,701)$; terakhir butir yang paling berkontribusi dari faktor keterandalan dalam bertindak adalah "mampu mengemukakan pendapat dan berkomunikasi" $(0,731)$.

\section{Ucapan Terima kasih}

Peneliti mengucapkan terima kasih kepada DPPM (Direktorat Penelitian dan Pengabdian kepada Masyarakat) Universitas Tarumanagara, atas dana penelitian yang diberikan.

\section{Daftar Pustaka}

Ardelt, M. (2000). Intellectual versus wisdom-related knowledge: The case for a different kind of learning in the later years of life. Educational Gerontology, 26(8), 771-789. doi: $10.1080 / 036012700300001421$.

Ardelt, M. (2003). Empirical assessment of a threedimensional wisdom scale. Research on Aging, 25(3), 275-324. doi: $10.1177 / 0164027503025003004$.

Ardelt, M. (2008). Being wise at any age. In S. J. Lopez (Ed.): Positive psychology: Exploring the best in people. Volume 1: Discovering human strengths (pp. 81-108). Westport, CT: Praeger.

Ardelt, M. (2018): Can wisdom and psychosocial growth be learned in university courses? Journal of Moral Education, 1-16 doi: 10.1080/03057240.2018.1471392.

Baltes, P. B., \& Smith, J. (1990). Toward a psychology of wisdom and its ontogenesis. In R. J. Sternberg (Ed.), Wisdom: Its nature, origins, and development (pp. 87-120). Cambridge, England: Cambridge University Press.

Baltes, P. B., \& Staudinger, U. M. (1993). The search for psychology of wisdom. Current Directions in Psychological Science, 2(3), 75-80. doi: 10.1111/1467-8721.ep10770914

Baltes, P. B., \& Staudinger, U. M. (1996). Interactive minds: Life-span perspectives on the social foundation of cognition. New York: Cambridge University Press.

Baltes, P. B., \& Staudinger, U. M. (2000). Wisdom: A metaheuristic (pragmatic) to orchestrate mind and virtue toward excellence. American Psychologist, 55(1), 122-135. doi: 10.1037/0003066x.55.1.122 
Basri, A. S. (2001). Kearifan dan manifestasinya pada tokoh-tokoh usia lanjut. (Tesis tidak diterbitkan). Depok: Fakultas Psikologi Universitas Indonesia.

Basri, A. S. (2006). Kearifan dan manifestasinya pada tokoh-tokoh lanjut usia. Makara Human Behavior Studies in Asia, 10(2), 70-78. doi: 10.7454/mssh.v10i2.25

Benedicovicova, J. \& Ardelt, M. (2008). The three dimensional wisdom scale in cross-cultural context: A comparison between America and Slova college students. Studia Psychologica, 50(2), 179-190. Retrieved from http://cejsh.icm.edu.pl/cejsh/element/bwme ta1.element.3fd69271-a40e-3170-9c6ccfe798bbafc6

Garcia-Campayo, J., del Hoyo, Y. L., Barcelo-Solerm A.B., Navarro-Gil, M., Borao, L., Giarin, V., Tovar-Garcia, R. R., \& Montero-Marin, J. (2018). Exploring the wisdom structure: Validation of the Spanish new short Three-Dimensional Wisdom Scale (3D-WS) and its explonatory power on psychological health-related variables. Frontier in Psychology, 9, 2-19. doi: 10.3389/fpsyg.2018.00692

Greene, J. A., \& Brown, S. C. (2009). The wisdom development scale: Further validity investigations. International Journal of Aging and Human Development, 68(4), 289-320. doi: 10.2190/ag.68.4.b

Gluck, J., Bischof, B., \& Siebenhuner, L. (2012). "Knows what is good and bad", "Can teach you things", "Does lots of crosswords": Children's knowledge about wisdom. European Journal of Developmental Psychology. 9(5), 582-598. doi: 10.1080/17405629.2011.631376.

Grossmann, I. (2018). Wisdom and how to cultivate it: Review of emerging evidence for a constructivist model of wise thinking. In press in European Psychologist. doi: 10.1027/10169040/a000302

Kramer, D. A. (2000). Wisdom as a classical source of human strength: Conceptualization and empirical inquiry. Journal of Social and Clinical Psychology, 19(1), 83-101. doi: 10.1521/jscp.2000.19.1.83

Pasupathi, M., Staudinger, U. M., \& Baltes, P. B. (2001). Seed of wisdom: Adolescents' knowledge and judgment about difficult life problems. Developmental Psychology, 37(3): 351-361. doi: 10.1037//0012-1649.37.3.351
Sahrani, R., Matindas, R. W., Takwin, B., \& Mansoer, W. W. (2014). The role of reflection of difficult life experiences on wisdom. Journal of the Indian Academy of Applied Psychology, 40(2), 315-323. Retrieved from http://jiaap.org/Listing_Detail/Logo/950e5b 4a-0b78-410d-898f-8ed0e8c32e0a.pdf

Sahrani, R., Suyasa, P. T. Y. S., \& Basaria, D. (2018). Kebijaksanaan berbasis Pancasila dan pengukurannya. Dalam Seri Sumbangan Pemikiran Psikologi untuk Bangsa 3: Psikologi dan Pendidikan dalam Konteks Kebangsaan (hal. 433-455). Jakarta, Indonesia: Himpunan Psikologi Indonesia.

Smith, J., \& Baltes, P. B. (1990). Wisdom-related knowledge: Age/cohort differences in response to life planning problems. Developmental Psychology, 26(3), 494-505. doi: 10.1037//0012-1649.26.3.494

Takahashi, M., \& Bordia, P. (2000). The concept of wisdom: A cross-cultural comparison. International Journal of Psychology, 35(1), 1-9. doi: 10.1080/002075900399475

Thomas, M. L., Bangen, K.J., Palmer, B.W., Sirkin, A'., Avanzino, J.A., Depp, C.A., Glorioso, D., Daly, R. E., \& Jeste, D. V. (2017). A new scale for assessing wisdom based on common domains and a neurobiological model: The San Diego Wisdom Scale (SD-WISE). Journal of Psychiatric Research, 108, 40-47. doi: 10.1016/j.jpsychires.2017.09.005.

Walsh, R. (2003). What is wisdom? cross-cultural and cross-disciplinary syntheses. Review of General Psychology, 3(19), 278-293. doi: 10.1037/gpr0000045

Webster, J. D. (2003). An exploratory analysis of a Self-Assessed Wisdom Scale. Journal of Adult Development, 10(1), 13-21. Retrieved from https://link.springer.com/article/10.1023/A: 1020782619051

Weststrate, N. M., \& Glück, J. (2017). Hard-earned wisdom: Exploratory processing of difficult life experience is positively associated with wisdom. Developmental Psychology, 53(4), 800-814. doi: $10.1037 /$ dev0000286.

Yang, S. (2017). The complex relations between wisdom and significant life learning. Journal of Adult Development, 24(4), 227-238. doi: 10.1007/s10804-017-9261-1. 
Lampiran A

Tabel A.1. Nilai Factor Loading Butir Karakteristik Kebijaksanaan Menurut Remaja

\begin{tabular}{|c|c|c|c|c|}
\hline \multirow[t]{2}{*}{ No. } & \multirow[t]{2}{*}{ Butir Karakteristik Kebijaksanaan } & \multicolumn{3}{|c|}{ Faktor } \\
\hline & & 1 & 2 & 3 \\
\hline 18 & Hati-hati dalam berbicara dan bertindak & 0,790 & & \\
\hline 25 & Mampu mengendalikan emosi & 0,698 & & \\
\hline 1 & Adil & 0,697 & & \\
\hline 5 & Berjiwa besar, mau memaafkan orang lain & 0,686 & & \\
\hline 10 & Bertanggungjawab & 0,680 & & \\
\hline 30 & Mau menerima kritik dan pendapat orang lain & 0,673 & & \\
\hline 41 & Menerima kelemahan diri dan mengakui kesalahan & 0,667 & & \\
\hline 32 & Memikirkan dampak keputusan, mempertimbangkan setiap tindakan & 0,626 & & \\
\hline 26 & Mempu menghadapi dan mencari solusi masalah & 0,613 & & \\
\hline 7 & Berkomitmen & 0,605 & & \\
\hline 11 & Bertindak tepat & 0,564 & & \\
\hline 37 & Mempunyai prinsip dan nilai moral yang baik & 0,534 & & \\
\hline 15 & Disiplin & 0,514 & & \\
\hline 42 & Menghormati orangtua, orang yang lebih tua* & 0,487 & 0,476 & \\
\hline 48 & Sabar, tenang* & 0,452 & 0,431 & \\
\hline 49 & Setia & & 0,701 & \\
\hline 20 & Humoris & & 0,689 & \\
\hline 46 & Ramah, murah senyum, sopan, beretika & & 0,663 & \\
\hline 36 & Mempunyai hati nurani & & 0,654 & \\
\hline 13 & Cinta damai & & 0,649 & \\
\hline 16 & Empati & & 0,617 & \\
\hline 38 & Mempunyai sikap nasionalisme & & 0,609 & \\
\hline 3 & Apa adanya & & 0,606 & \\
\hline 9 & Bersyukur & & 0,601 & \\
\hline 31 & Mau menolong, tulus ikhlas & & 0,569 & \\
\hline 39 & Menaati aturan yang berlaku di masyarakat & & 0,564 & \\
\hline 43 & Menjalankan agamanya & & 0,553 & \\
\hline 47 & Rendah hati & & 0,546 & \\
\hline 44 & Peduli orang lain dan lingkungan & & 0,539 & \\
\hline 34 & Memperhatikan kerapihan & & 0,533 & \\
\hline 52 & Tidak mementingkan diri sendiri* & 0,414 & 0,472 & \\
\hline 19 & Hemat* & & 0,412 & \\
\hline 17 & Fleksibel, mau menerima perubahan* & & 0,406 & \\
\hline 33 & Memiliki tujuan dan makna kehidupan* & & 0,397 & \\
\hline 24 & Mampu mengemukakan pendapat, berkomunikasi & & & 0,731 \\
\hline 50 & Tegas & & & 0,657 \\
\hline 29 & Mau bekerja keras, tidak mudah menyerah & & & 0,636 \\
\hline 21 & Konsisten, berkomitmen & & & 0,613 \\
\hline 28 & Mandiri & & & 0,608 \\
\hline 45 & Percaya diri & & & 0,598 \\
\hline 27 & Mampu menilai diri sendiri dan orang lain & & & 0,597 \\
\hline 12 & Cerdas, cerdik, kritis, kreatif & & & 0,591 \\
\hline 22 & Mampu bekerjasama dan menyesuaikan diri dengan orang lain & & & 0,569 \\
\hline 4 & Berani mengambil keputusan & & & 0,559 \\
\hline 6 & Berjiwa kepemimpinan, berkharisma, berwibawa, menjadi teladan* & 0,547 & & 0,551 \\
\hline 8 & Berpikir positif, berpikiran maju, berwawasan luas & & & 0,550 \\
\hline 51 & Teliti & & & 0,515 \\
\hline 23 & Mampu memotivasi dan menasehati orang lain* & 0,457 & & 0,466 \\
\hline
\end{tabular}


Lampiran A.

Tabel A.2. Tiga Dimensi Karakteristik Kebijaksanaan Menurut Remaja

\begin{tabular}{|c|c|c|c|c|}
\hline \multirow{2}{*}{ No. } & \multirow{2}{*}{ Butir Karakteristik Kebijaksanaan } & \multicolumn{3}{|c|}{ Faktor } \\
\hline & & 1 & 2 & 3 \\
\hline 18 & Hati-hati dalam berbicara dan bertindak & 0,790 & & \\
\hline 25 & Mampu mengendalikan emosi & 0,698 & & \\
\hline 1 & Adil & 0,697 & & \\
\hline 5 & Berjiwa besar, mau memaafkan orang lain & 0,686 & & \\
\hline 10 & Bertanggungjawab & 0,680 & & \\
\hline 30 & Mau menerima kritik dan pendapat orang lain & 0,673 & & \\
\hline 41 & Menerima kelemahan diri dan mengakui kesalahan & 0,667 & & \\
\hline 32 & Memikirkan dampak keputusan, mempertimbangkan setiap tindakan & 0,626 & & \\
\hline 26 & Mempu menghadapi dan mencari solusi masalah & 0,613 & & \\
\hline 7 & Berkomitmen & 0,605 & & \\
\hline 37 & Mempunyai prinsip dan nilai moral yang baik & 0,534 & & \\
\hline 40 & Menepati janji, dapat dipercaya, jujur & 0,518 & & \\
\hline 2 & Amanah & 0,518 & & \\
\hline 15 & Disiplin & 0,514 & & \\
\hline 49 & Setia & & 0,701 & \\
\hline 20 & Humoris & & 0,689 & \\
\hline 14 & Demawan & & 0,674 & \\
\hline 46 & Ramah, murah senyum, sopan, beretika & & 0663 & \\
\hline 36 & Mempunyai hati nurani & & 0,654 & \\
\hline 13 & Cinta damai & & 0,649 & \\
\hline 16 & Empati & & 0,617 & \\
\hline 38 & Mempunyai sikap nasionalisme & & 0,609 & \\
\hline 3 & Apa adanya & & 0,606 & \\
\hline 9 & Bersyukur & & 0,601 & \\
\hline 31 & Mau menolong, tulus ikhlas & & 0,569 & \\
\hline 39 & Menaati aturan yang berlaku di masyarakat & & 0,564 & \\
\hline 43 & Menjalankan agamanya & & 0,553 & \\
\hline 47 & Rendah hati & & 0,546 & \\
\hline 44 & Peduli orang lain dan lingkungan & & 0,539 & \\
\hline 34 & Memperhatikan kerapihan & & 0,533 & \\
\hline 35 & Mempunyai banyak pengalaman hidup & & 0,512 & \\
\hline 24 & Mampu mengemukakan pendapat, berkomunikasi & & & 0,731 \\
\hline 50 & Tegas & & & 0,657 \\
\hline 21 & Konsisten, berkomitmen & & & 0,613 \\
\hline 28 & Mandiri & & & 0,608 \\
\hline 45 & Percaya diri & & & 0,598 \\
\hline 12 & Cerdas, cerdik, kritis, kreatif & & & 0,591 \\
\hline 22 & Mampu bekerjasama dan menyesuaikan diri dengan orang lain & & & 0,569 \\
\hline 4 & Berani mengambil keputusan & & & 0,559 \\
\hline 8 & Berpikir positif, berpikiran maju, berwawasan luas & & & 0,550 \\
\hline 51 & Teliti & & & \\
\hline
\end{tabular}

